\title{
Forests of Alabama, 2018
}

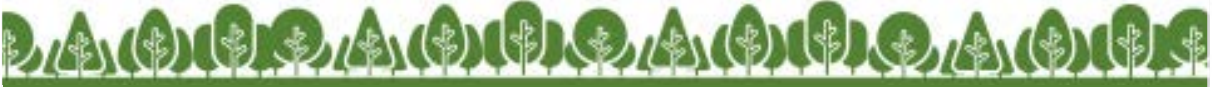 \\ $69 \%$ forested}

Alabama has an estimated $23,095,384$ acres of forest land.

This resource update is a brief look at some of the basic metrics that describe the status of and changes to forest resources in Alabama. This information is based on field data collected using the USDA Forest Service Forest Inventory and Analysis (FIA) annualized sample design, and it is updated yearly.
Alabama has 5,606 sample plots across the State, of which 4,273 are currently forested. Each year, about 14-20 percent of these plots are visited and measured by field crews. Data used in this update were accessed from the FIA database on 05/09/2019.

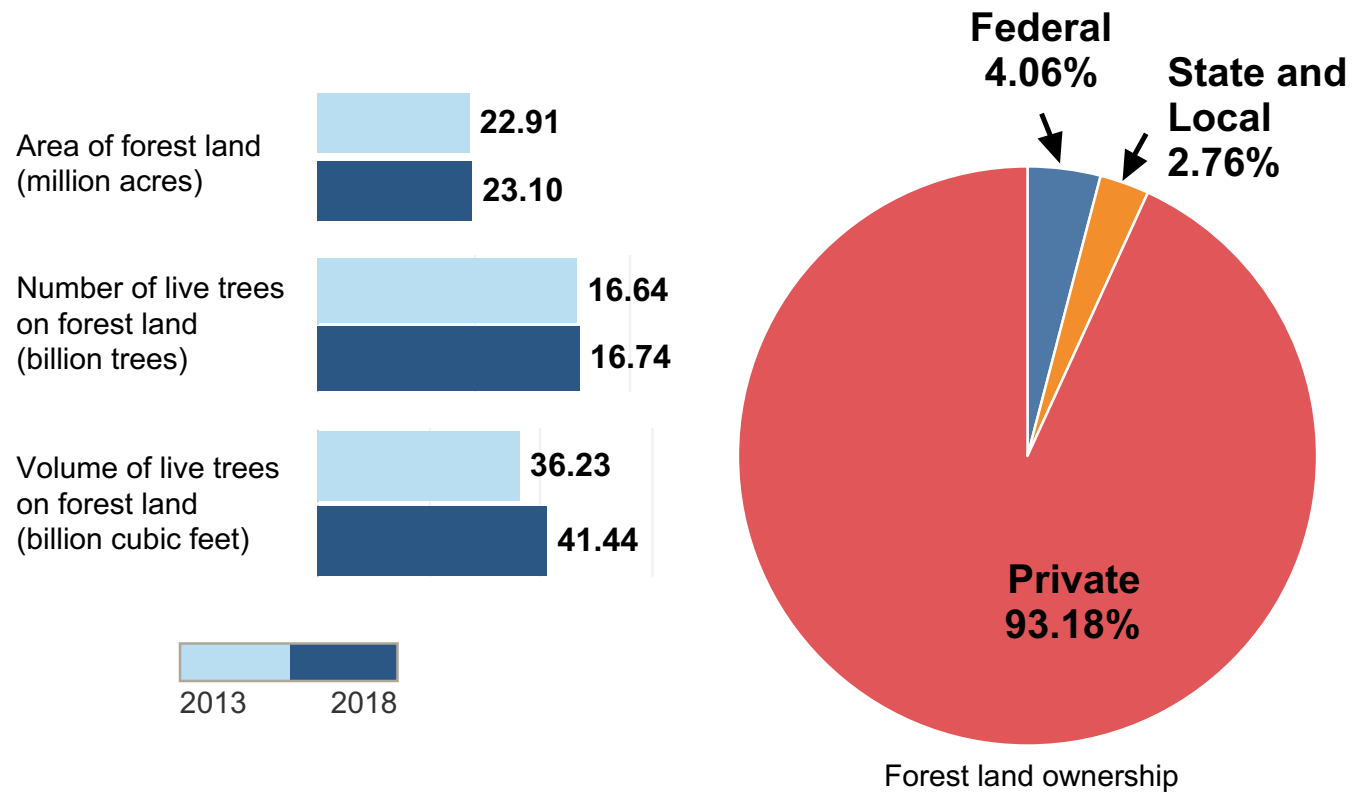

81,038 acres of nonforest revert back to forest annually*

77,418 acres of forest land convert annually* to nonforest

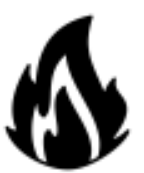
415,205 acres of forest land are disturbed annually* by fire

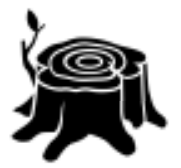

784,209 acres of forest land are treated (harvest, thinning, etc.) annually*

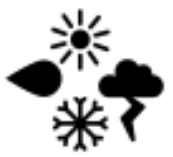

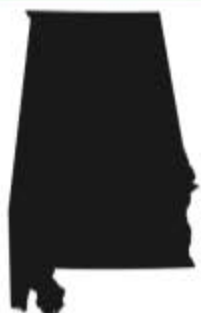

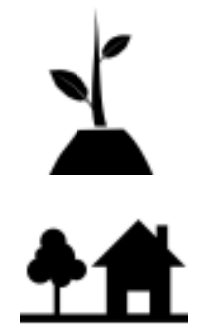

66,152 acres of forest land

are disturbed annually* by weather events

\section{USDA Forest Service - Forest Inventory \& Analysis}

The estimates presented are based on data retrieved from the FIA database (05/09/2019) and may not reflect the most recent data available from the FIA program. Note - this publication does not include estimates of uncertainty. The most current data and sampling error for the estimates above can be found by visiting https://www.fia.fs.fed.us/.

*Average annual estimates are based on data collected across 5-10 years and may not be indicative of the nominal year presented in the title by itself. 


\section{Forests of Alabama, 2018}

\section{How to cite this publication}

USDA Forest Service. 2019. Forests of Alabama, 2018. Resource Update FS-180. Asheville, NC: U.S. Department of Agriculture, Forest Service. 2p. https://doi.org/10.2737/FS-RU-180.

\section{Archived Versions}

This report can be found on the USDA Forest Service publication database, Treesearch, at: https://doi.org/10.2737/FS-RU-180 .

Archived versions of resource updates can be found by searching Treesearch using keywords "Forest Inventory" and "Alabama" here: https://www.fs.usda.gov/treesearch/.

\section{National Woodland Owner Survey}

The National Woodland Owner Survey (NWOS) collects and reports on multiple attributes of forest land ownership. Details of the NWOS program can be found here: https://www.fia.fs.fed.us/nwos/.

The most recent NWOS Factsheet for Alabama can be found here: https://www.nrs.fs.fed.us/pubs/52397/.

\section{Additional Resources}

The application that produced this resource update was developed using data from the USDA Forest Service Forest Inventory and Analysis database (FIADB): https://apps.fs.usda.gov/fia/datamart/datamart_excel.html .

Tables for Alabama, 2018 can be found here: https://doi.org/10.2737/FS-RU-180-Tables

The FIA one-click application can be found here:

https://public.tableau.com/views/FIA_OneClick_V1_2/StateSelection?\%3AshowVizHome=no/.

Bechtold, W.A.; Patterson, P.L., eds. 2005. The enhanced Forest Inventory and Analysis program—national sampling design and estimation procedures. Gen. Tech. Rep. SRS-80. Asheville, NC: U.S. Department of Agriculture Forest Service, Southern Research Station. 85 p.

https://doi.org/10.2737/SRS-GTR-80.

NOTE: Some of the above links will not be active until the resource update has been approved for official publication. 